\title{
Rainfall Variability and Food Crop Vulnerability in Ndu Sub-Division, North West Region of Cameroon
}

\author{
Chiarity Zetem Chiambah ${ }^{1} \&$ Cordelia G. Kometa ${ }^{2}$ \\ ${ }^{1}$ Department of Geogrqphy, Facuty of Social and Management Sciences, University of Buea, Cameroon \\ ${ }^{2}$ Department of Topography and Real Estate Management, Higher Technical Teachers' Training College, Kumba, \\ Cameroon \\ Correspondence: Chiarity Zetem Chiambah, Department of Geography, Facuty of Social and Management \\ Sciences, University of Buea, Cameroon. E-mail: c.chiambah@yahoo.com; ckgiven@yahoo.com
}

Received: September 1, 2019

Accepted: September 27, 2019 Online Published: September 30, 2019

doi:10.5539/jgg.v11n3p39

URL: http://dx.doi.org/10.5539/jgg.v11n3p39

\begin{abstract}
Little scientific evidence exists in the context of climate variability and food crop production in Ndu. This study seeks to assess the impact of rainfall variability on food crop vulnerability in Ndu Sub-Division. The primary data were gotten through field surveys. A total of 200 farmers were sampled and questionnaires were administered to them. Descriptive and inferential statistical techniques were employed to analyze the data. Results were presented in tables and climographs. Formulated hypotheses were tested using the least square regression model to establish the extent of exposure and sensitivity of rainfall variability on food crop production. The Pearson Product Moment Correlation Coefficient was used to describe the trends of variations in rainfall. Statistically, rainfall accounted for $19.5 \%$ of variability in maize production while $50.87 \%$ accounted for variability in beans production. Furthermore, $30.1 \%$ accounted for variations in potatoes production. From these statistics it was then concluded that rainfall variability minimally affects maize and beans but had a significant effect on maize production in Ndu. The research study also revealed that rainfall shows a decreasing trend. The study recommended, amongst others the need for farmers to adopt more sustainable agricultural practices and the increased use of more resistant crop species that can withstand exposure and sensitivity to rainfall variability. The study concluded that a bottom-up approach should be employed in order to improve on the adaptive capacities of the agricultural sector in Ndu.
\end{abstract}

Keywords: Agriculture, Climate Variability, Vulnerability

\section{Introduction}

Climate remains a critical factor in determining the performance of natural and man-made systems. Crucial amongst these man-made systems is agriculture. Changes in climatic conditions can therefore positively or negatively affect biomass production in agricultural lands. In contemporary times, there has been growing variability and change in the world's climate. These changes are more driven by human activities even though natural ones like volcanic eruptions equally play a significant role. During the course of the $21^{\text {st }}$ Century, scientific evidence has shown that global-average surface temperatures are increasing by $2-4.5^{\circ} \mathrm{C}$ as greenhouse gas concentrations in the atmosphere are increasing. At the same time, it is said that there will be changes in precipitation, and climate extremes such as hot days, heavy rainfall and drought are expected to increase in many areas. The combination of global warming will be superimposed on decadal climate variability, such as that caused by the Inter-decadal or Pacific Decadal Oscillation, and inter-annual fluctuations caused by the El Nino/Southern Oscillation and the North Atlantic Oscillation. All these may lead to a century of increasing climate variability and change that are expected to be unprecedented in the history of human settlement and agrarian activities (United Nations Framework Convention on Climate Change UNFCCC, 1992). In a study by (Rosenweig \& Hillel, 1995), they expressed their views that extreme meteorological events such as high temperatures, dry spells, frequent droughts and reducing rainfall do not only reduce water supplies but also reduce the amount of water needed for plant transpiration.

Vulnerability in the context of climate change is "the degree to which a system is susceptible to, and unable to cope with the adverse effects of climate change, including climate variability and extremes (IPCC, 2007). This definition specifically highlights three components of vulnerability in the climate change context exposure, 
sensitivity and adaptive capacity. Exposure in an agricultural system represents the background climatic conditions and stimuli against which the system operates as well as any changes in those conditions. Thus, exposure as a component of vulnerability is not only the extent to which a system is subjected to significant climatic variations, but also the degree and duration of these variations (Adger, 2006). The sensitivity of an agricultural system to climate change reflects the degree to which the system is affected either adversely or beneficiary by climate variability or change. Exposure and sensitivity together describe the potential impact that climate change can have on a system. However, it has to be noted that even though a system may be considered as being highly exposed and/or sensitive to climate variability and change, it does not necessarily mean that it is vulnerable. This is so because neither exposure nor sensitivity account for the capacity of a system to adapt to climate change (that is its adaptive capacity), whereas vulnerability is the net impact that remains after adaptation is taken into account. Adaptive capacity has been defined as the ability or the potential of a system to adjust successfully to climate change including climate variability and extremes to moderate potential damages, to take advantage of opportunities and/or to cope with the consequences (IPCC, 2007).

Rainfall in the study area is high with an annual value of about $2000 \mathrm{~mm}$ per year. Ndu possesses a cold misty climate. Its moderate elevation has conditioned the climate of this region for agricultural production. Despite the favourable climatic conditions and soils for agricultural production in Ndu Sub-Division, the sector is faced with variability in climatic parameters whose effects are expressed in delayed onset of rains, early onset of rains, and increase pest and disease proliferation on food crops.

\section{The Problem}

Ndu Sub-Division is one of the remarkable areas in Donga-Mantung Division noted for the production of food crops like maize, beans and potatoes. However, there has been limited focus on the effect of the varying climate on the activities of local farmers. Ndu Sub-Division in the last 34years has shown variations in its climatic parameter of rainfall. With the dominant crop of the study area being maize, beans and potatoes, drought often characterized by the late onset of rains like in the case of the 2003, 1997 and the 1998 droughts or the occasional occurrence of torrential downpours like the case of the 1999, 2007 and 2008 have often severely affect these crops; consequently, reducing yields. The last ten years have been characterized by heavy down pour during the pod formation season of crops leading to the destruction of flowers and a reduction in the yields of beans. Variations at the onset of the rains have led to a complete shift in the agricultural calendar from land preparation to planting and finally harvesting. Pest and disease activities have increased with increase variability in the climatic parameters of temperatures and rainfall in Ndu. These pests and diseases vary with crop species and their intensity of attack also varies with altitude. So far, studies have been carried out in Ndu, in relation to climate variability and food crop production. In addition, the impacts of climate variability on tea production have also received great attention. But very little is known in the context of rainfall variability and food crop vulnerability. Given the fact that more than $80 \%$ of the population of this area depend on food crop production for their livelihood coupled with the fact that they depend solely on rainfall for crop cultivation, it is imperative that this study be carried out to help this agrarian population to be able to reduce the adverse impacts of climatic caprices on their crops.

\section{Location of Study Area}

The study area is Ndu Sub-Division in Donga- Mantung Division. This area lays between Latitude $6^{\circ} 20^{\prime \prime}$ and $6^{\circ} 40^{\prime \prime}$ North and Longitude $6^{\circ} 25^{\prime \prime}$ and $11^{\circ} 20^{\prime \prime}$ east of the Green Which Meridian. It covers a total surface area of $1350 \mathrm{sqkm}$. Ndu is bounded to the North by Nkambe Central, to the west by Nwa Sub-Division, to the east by Nkum Sub-Division. It is the headquarters of Ndu Sub-Division (Ndu Council, 2010). Figure 1 locates Donga-Mantung in the North West Region and Ndu Sub-Division in Donga-Mantung Division. Figure 1 is the location map of Ndu Sub-Division. 


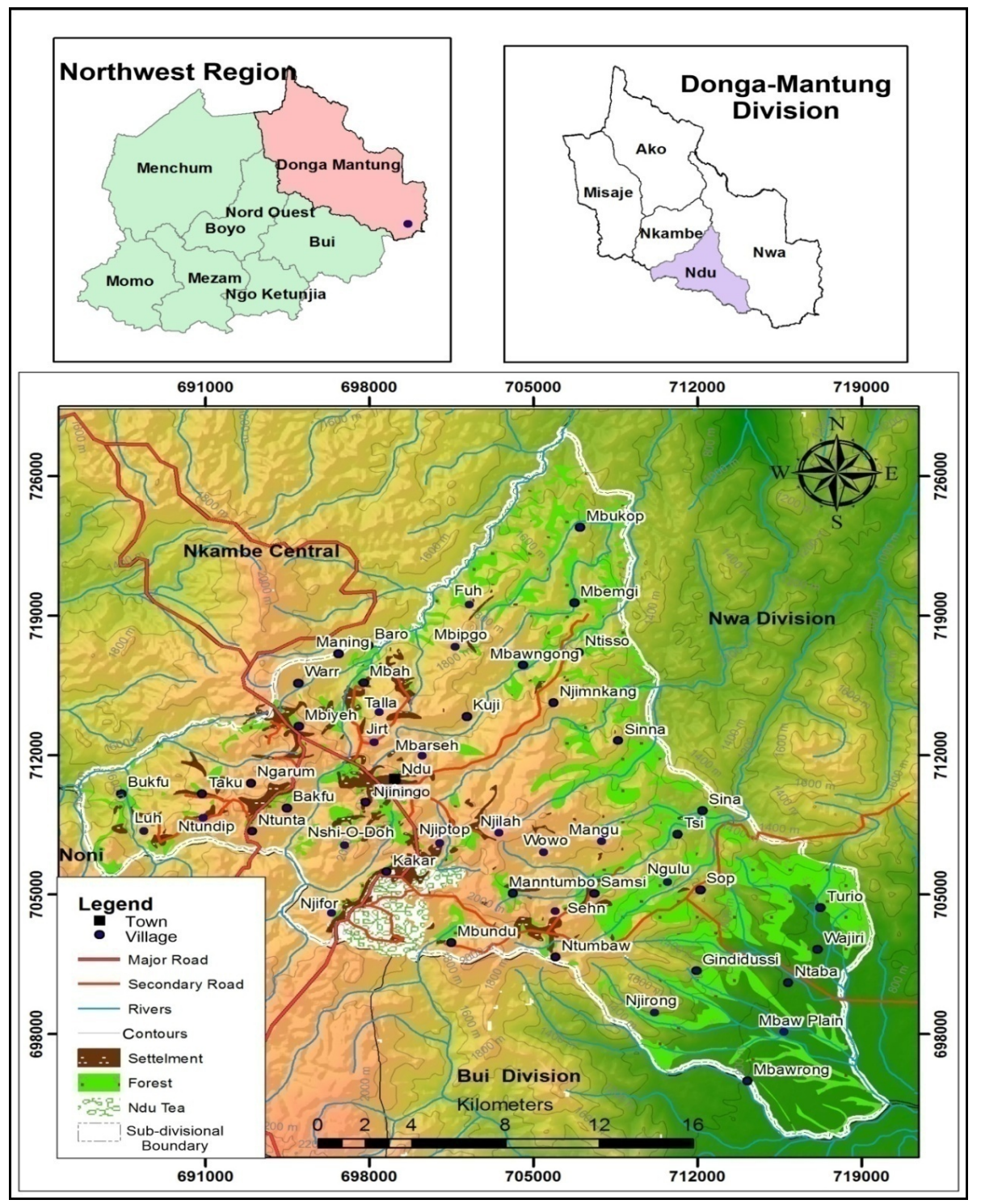

Figure 1. Location Map of Ndu Sub-Division

Source: Adapted from the map of Nkambe (2004).

\section{Research Methodology}

This study made use of the standard social science methodology. A total of two hundred questionnaires were distributed during the study in 18 villages of Ndu Sub-Division. The household questionnaires involved semi-structured, open ended, and closed ended questionnaires conducted across villages in the 3 micro ecological zones. Table 1, shows these villages and their heights above the sea. Historical crop statistics for the yields of maize, beans and potatoes were obtained from the Sub-Divisional Delegation for Agriculture and Rural Development for a period of eight years. Crop production was measured in tons. A four year moving average formulae was used to derive missing crop data for the years for which data were not available. This was achieved with the help of an SPSS package (E-views 5.0). Crop data were then available from the year 2000 to 2015. Climatic data was obtained from the Cameroon Tea Estate Meteorological station in Ndu. This rainfall data gave measurements of monthly and annual rainfall. Furthermore, memoires, theses and articles written on the various concepts bearing on the issues related to rainfall variability and crop production were reviewed. This research utilized two sub-categories of purposive sampling, namely, expert sampling and snowball sampling. Interviews were conducted with some government officials on some of the issues identified. 
Table 1. Micro Ecological Zones and their Corresponding Altitudes in different villages within the zones

\begin{tabular}{lll}
\hline Micro ecological zone & Distance in meters above sea level & Villages that make up the zone \\
\hline Lowlands & $600 \mathrm{~m}$ to $1000 \mathrm{~m}$ & Ntamruh, Ntaba, Sop, Luh, Njimsar, Ntayi \\
Midlands & 1000 to $1500 \mathrm{~m}$ & Mangu, Ntumbaw, Shen, Nshi-o-Doh, Kugha, Mbanfung \\
Highlands & 1500 to $2300 \mathrm{~m}$ and above & Mbiye, Njifor, Kakar, Ndu, Njimkang, Ntissoh \\
\hline
\end{tabular}

Source: Field Work (2015)

\section{Literature Review}

An extensive survey was conducted to collect literature in all the aspects of the study. Rainfall is a key determinant of crop growth and yields in rain fed agricultural areas as it is the main source of soil moisture. Plants assimilate water through their roots and transpire it through small pores in their leaves called stomata. Water lost via transpiration has to be replaced by water available in the soil (soil moisture) to enable plants to grow. When soil moisture is insufficient to cover the water needs of a plant, water stress occurs and plant growth is hindered. Plants have different water requirements depending on their physiology, phenological stage and the climatic zone where they are grown. Some small plants possess smaller leaf surface area than larger plants; smaller plants transpire less and thus need less water (Cothren et al., 2000). Other plants have particular water needs during critical growth stages; for instance, in hot, dry, windy and sunny areas, plants transpire more and thus have higher water requirements than in cool, humid, cloudy and windless areas (Critchley \& Siegert, 1991). This explains why crops flourish more during the wet season than in the dry season.

Mendelssohn, (2009) in his study on the impact of global warming on agriculture during the past century indicated that, changes in temperature patterns have had a direct impact on the number of frost days and the length of growing seasons with significant implications for agriculture and forestry. The largest predicted damage from climate variability and change he said is on the agricultural sector especially in Sub-Saharan Africa. Agriculture is predicted to be especially vulnerable in this region because it already endures high heat, low precipitation, and insufficient access to resources like land, water and management capabilities, wealth, technology, education, ineffective institutional structures among others. On the other, Rosenweig \& Hillel (1995) expressed their views that extreme meteorological events such as high temperatures, dry spells, frequent droughts and reducing rainfall do not only reduce water supplies but also increases the amount of water needed for plant transpiration. They noted that a wide variety of adaptive actions may be taken to lessen or overcome the adverse effects of climate on agriculture. At the level of farms, adjustments may include the introduction of later maturing crop varieties or species, switching cropping sequences, early sowing, and improving irrigation efficiency. Some options like switching crop varieties may be less expensive while others such as introducing irrigation especially high-efficiency water conserving technologies involve major investments. The major adaptive response will be the breeding of heat and drought resistant crop varieties by utilizing genetic resources that may be better adapted to new climatic and atmospheric conditions.

Atkins et al. (1998) in a study on the calculated methodology for measurement of vulnerability and how to construct a suitable composite vulnerability index for developing countries suggested that small states are more prone to vulnerability when compared to large states. On the other hand, Handmer et al. (1999) examined the coping mechanisms to environmental shock or hazard brought about by biophysical vulnerability. Factors like institutional stability and strength of public infrastructure are of crucial importance in determining the vulnerability to climate change. A well connected population with appropriate public infrastructure will be able to deal with a hazard effectively and reduce the vulnerability. Such a society could be said to have low social vulnerability. If there is an absence of institutional capacity in terms of knowledge about the event and ability to deal with it, then such a high vulnerability is likely to ensure that biophysical risk turns into an impact on the human population. The study area, for example, has only one reliable weather station at the Cameroon Tea Estate. Weather forecast for the whole division is difficult given the fact that altitudinal differences are observed in the location of its villages. In situations of a hazard, a sub-division like Nkambe will be less vulnerable as compared to Ndu; first because of its viability in terms of awareness coupled with the many specialists at the Divisional level and weather stations that are available at their disposal with competent people who key in the records and give interpretations to the effects on crops. In such situations, the information is immediately disseminated to farmers in order for them to adjust in situations of a suspected hazard. This is not the case in Ndu where, the main reason for weather monitoring is for the tea farms and not food crops per say.

From the above literature, the authors have focused more on the effects of climate variability and change on agriculture as a hold and water resources. Again, vulnerability to agriculture has not been related to 
specific crops. But this study attempts an analysis of the extent of food crop exposure and sensitivity as a function of rainfall variability.

\section{Annual Rainfall Trends for Ndu (1981 to 2014)}

Rainfall variability in the strict sense refers to changes in the amount of rain received in a specific geographic space within a defined period. The variation could be monthly, annually, seasonally or decadal. Annual rainfall totals of rainfall were calculated for each year. From these totals, the mean annual rainfalls were calculated from where deviations from the mean were gotten. A square of these deviations gave the standard deviation. Furthermore, the coefficient of variations was calculated. Figure 2 represents Rainfall Trends for Ndu from 1981 - 2014. There is an inverse relationship, which exists between rainfall amount and variability (Ayoade, 1988; in Amawa 1999). As the amount of rainfall reduces, there is a tendency for increasing variability. Such variability has a serious economic consequence especially in highly vulnerable sub-humid regions. This is the case in Ndu where such variabilities have caused widespread crop failure and a situation of near famine especially during the 1982/1983 and 1997/1998 drought years. Figure 2 show a decreasing trend in rainfall in the study area. According to data from Hawkins and Brunt (1965), the mean annual rainfall for Ndu was 2172mm, Ndu Baptist School $2113 \mathrm{~mm}$ for the period running from 1953 to 1960 . The 1972.8 rainfall mean in 2014 can possibly be stated that rainfall had been on the decrease from the 1950 s to the 2000 s.

Figure 2 shows 10 positive deviations against seven negative deviations. The most significant negative deviations were recorded in 1982/1983 (-460mm), 1997/1998 (-350), 2001 and 2004 (-300), 2011/2014. Rainfall has been declining over the years in a fluctuating pattern as depicted by Figure 2. Thus, the general fall in rainfall in the sub-division reflects a global character.

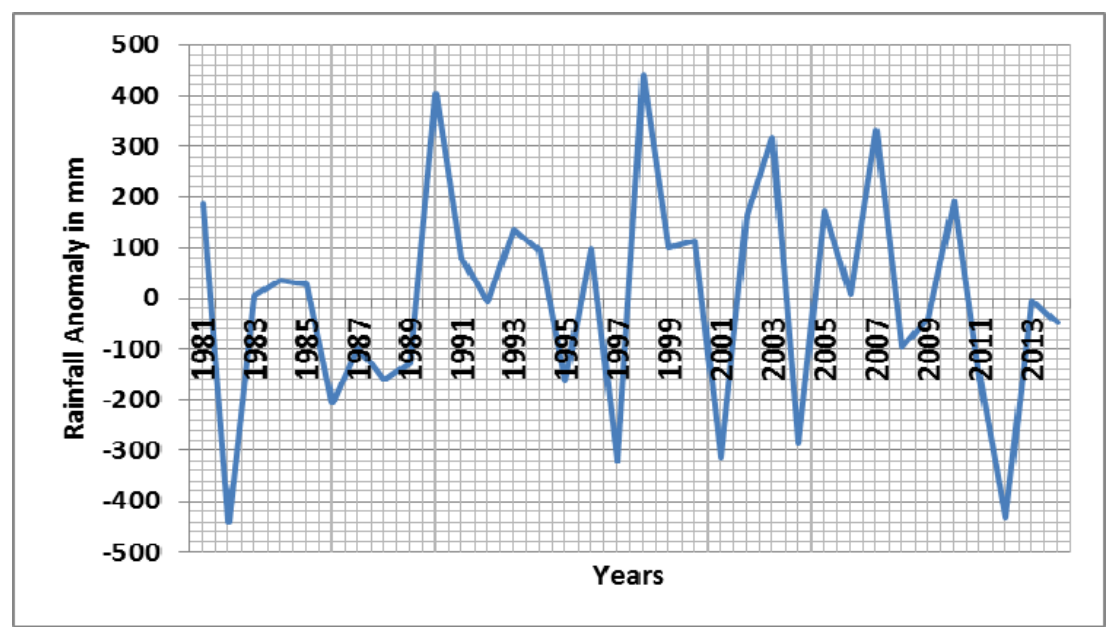

Figure 2. Annual Rainfall Variations for Ndu Sub-Division (1981 - 2014)

Source: computed from Climate data, 2015.

Observations of rainfall pattern over the years show a direct oscillation pattern with the El Niño phenomenon. The negative anomaly observed in the amounts of rainfall coincides with the El Niño years. The 1982/1983 El Niño was described as the El Niño of the time with a negative rainfall deviation of $-460 \mathrm{~mm}$. One of the most devastating El Niño that occurred after this was the 1997/1998 occurrence with a negative rainfall of -350 . The years 2001 and 2004 again correspond to El Niño years and a negative rainfall anomaly of -300 was recorded. The 2011/2014 years again recorded a significant negative anomaly -430. This period aside of the fact that they coincide with El Niño occurrence, these years have been characterized by extended dry periods and extended dry spells that intersperse the wet season. The increasing variations from 1989 to 2014 are due to a multiplicity of El Niño occurrences. There have been eight El Niños between this period with two very strong El Niño and six strong occurrences. These negative anomaly years most often corresponded with years of crop failures in the sub-division.

\section{Implications on Food Crop Production}

Climate variability especially through the occurrence of the El Nino has severe impact on food crop production as was the case of Ndu Sub-Division. Maize yields dropped drastically during the 1982/83 and the 1997/1998 
droughts because rainfall was insufficient for successive growth during its vegetative growth period and the crops were bound to fail. This was the same with beans where during its pod formation period there was not sufficient moisture to facilitate growth. As a result, most of the bean plants were affected by the dwarf virus that is associated with high temperature (MINADER, Phytosanitary department; Nkambe, 2014). The potatoes plants all were sunken because of excessive evapotranspiration with no rains. Moreover, potatoes during their tuber enlargement need alternating sunshine and rainfall but these years were characterized by less rainfall so the tubers could not form properly. These conditions conform to a study carried out in Kogi state, Nigeria Ibitoye, on the effects of rainfall and temperatures on maize yields. This study revealed that $36 \%$ of variations in maize production in this state were accounted for by variations in rainfall. The study used a ten-year period, that is, from 2001 to 2010. Variation in food crop production in Ndu Sub-Division is presented in Table 2.

From Table 2 crop yields show a corresponding decrease with the negative anomalies of rainfall. These years were 2001, 2004, 2011, 2012, 2013 and 2014. Annual rainfall trends in the sub-division showed years with significant increase in rainfall above the mean. These years, are, 1990/91, 1998, 1991, 2007.

Table 2. Crop Production for Ndu Sub-Division from 2000 to 2015 in Tons

\begin{tabular}{llll}
\hline Year & Maize & Beans & Potatoes \\
\hline 2000 & 50388.17 & 10907.36 & 22012.51 \\
2001 & 49395.03 & 11105.46 & 25025.01 \\
2002 & 50968.62 & 11383.39 & 21520.59 \\
2003 & 53576.5 & 10672.86 & 18512.97 \\
2004 & 47612.55 & 11232.22 & 15938.12 \\
2005 & 45422.44 & 10142.85 & 13738.39 \\
2006 & 57263 & 12096 & 37340 \\
2007 & 64008 & 12773 & 43100 \\
2008 & 23756.75 & 7120.25 & 494.0625 \\
2009 & 36662 & 14029 & 467.25 \\
2010 & 19075 & 4696 & 489 \\
2011 & 19400 & 4816 & 540 \\
2012 & 19890 & 4940 & 480 \\
2013 & 20400 & 5069 & 360 \\
2014 & 20931 & 5200 & 558 \\
2015 & 5038 & 5150 & 549 \\
\hline
\end{tabular}

Source: Projections from Crop Production Data from the Sub-Divisional Delegation for Agriculture and Rural Development in Ndu.

These years fall between minor El Niño years. This reason could account for the significant increases in rainfall received for these years. This only helped to confirm one of the characteristics of the El Niño that their effects vary with each El Niño occurrence. The year 1991 recorded a positive rainfall anomaly of $400 \mathrm{~mm}$. This year was closely followed by 1992 with a positive rainfall anomaly of $460 \mathrm{~mm}$.

Again, 2002/2003 and 2007/2008 are all El Nino years. Besides, the heavy rains noticed during these years; they were accompanied by frequent wind storms and hail storms that destroyed bean flowers and leaves of crops during their pod formation season. The 2003, 2004, 2007 and 2008 episodes are reflected in their harvest as depicted by Table 2 . These years corresponded with good yield in maize while beans and potatoes that are very sensitive to intense rainfall experienced a reduction.

A potato plant, for example, under high moisture content is liable to late blight. Bean plants in such condition are affected by aphids in the field. The 2007/2008 rains were so heavy up to periods of harvest that storage was difficult and most beans on the high altitude areas of Mbiyeh, Kakar, Njiefor, Njimkang and so on got decayed because of the high humidity and clouded skies that prevented sunshine for a greater part of the wet season.

Mean monthly rainfall amounts for the sub-division are represented on Figure 3. From the calculated mean rainfall amounts received for each month, the lowest rainfall amounts were recorded in the months of January $(5.1 \mathrm{~mm})$ while the highest figure was recorded in September with a rainfall amount of $321.6 \mathrm{~mm}$. It should be noted that the mean monthly rainfall amounts also determine agricultural production in Ndu. The dry season months correspond to periods of land preparation for agricultural activities since they constitute the months with 
little moisture available for crop cultivation. The wet season months correspond to months of intense agricultural activity because of the abundant moisture in the soil for crop production. The coefficient of variation (C.V) was used to calculate rainfall variability in Ndu Sub-Division. The calculated coefficient of variation (C.V) was expressed as a percentage and indicated the dependability of crop production.

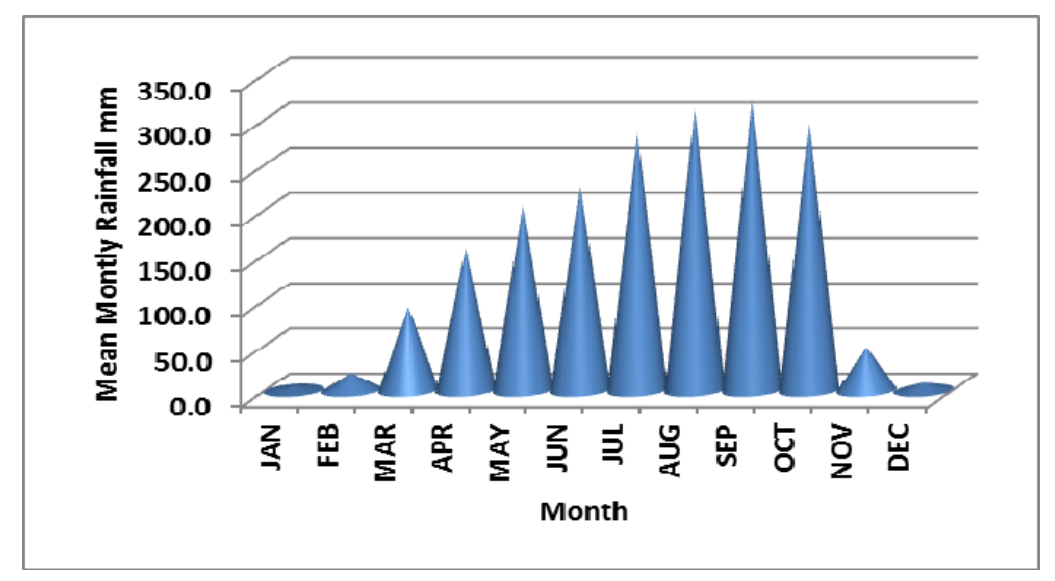

Figure 3. Mean Monthly Rainfall Amounts in Ndu Between the Periods 1981 - 2014

Source: Computed from rainfall data for Ndu (1981-2014).

The threshold levels of C.V for the interpretation are based on an annual and seasonal basis. Annual threshold of rainfall is $<25 \%$, while seasonal rainfall threshold is $<50 \%$ (Storch \& Zweir, 1999). This implies that, an annual $\mathrm{CV}$ above $25 \%$ is not reliable and indicates high rate of rainfall variability while a CV of $25 \%$ and below is reliable for rain fed dependable activities. Monthly rainfall CVs varies with the months. This means that rainfall is reliable and dependable for some months while for some months it is very unreliable for crop production. The highest CVs were recorded in the months of January (238.3), February (130.2), November (80.7) and December (309.5). These CVs are far above the 50\% threshold for reliability of rainfall. These months correspond with the dry season months where little or no rain is received. Figure 4 presents variations in monthly CVs for Ndu Sub-Division.

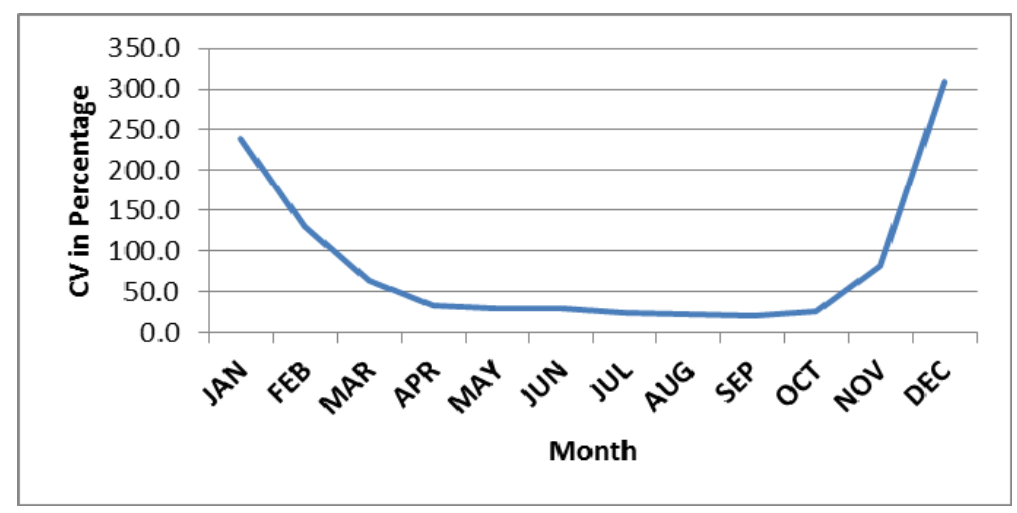

Figure 4. Variations in Monthly CV, Depicting the rate of Reliability of Rainfall Amounts Source: Computed from Rainfall data for Ndu (1981-2014).

From calculations of CV, December recorded the highest CV. This is an indication that rainfall in this month is extremely variable as the figure went far above the threshold of $<50 \%$. This high variability in rainfall during these months explains why agricultural activities slow down. These months are characterized by scorching overhead sun, increased evapotranspiration, blue skies and dusty atmospheres in the study area. For agriculture to survive in these months, irrigation schemes must be employed during these periods. The CVs for the wet season months showed reliability as a majority of the CVs fell below the threshold of $50 \%$. The month with the lowest CV was September (19.7\%) indicating relatively low variability in rainfall for this month and high 
reliability on rainfall in this month for agricultural activities. It should be noted that although March is classified as a wet season month it registered a CV of $63.3 \%$ which is above the $50 \%$ threshold for reliability. This figure could be accounted for by the extended dry periods that have been witnessed in the last ten years in the study area in the months of March. This is increasingly rendering March rainfall very variable and unreliable for agriculture. Rainfall on an annual basis is very reliable with minimal variations. The annual CV for the period under consideration was gotten as $11.1 \%$. This figure is far below the annual threshold for measuring variability which is $25 \%$. This is an indication that that on annual basis rainfall variability in the sub-division is minimal and dependable for crop production and animal husbandry all year round.

\section{Perceptions of Climate Variblity and Food Crop Vulnerability in Ndu Sub-Division}

Rainfall variability constitutes an important component of the agricultural system's exposure to stimuli. Minimal variations in rainfall have been noticed in Ndu between 1981-2014 with an annual coefficient of variation of $11.1 \%$. On an annual scale, the variations are minimal but seasonally the variations vary significantly especially with the dry season rainfall. The dry seasons registered a CV of $77.1 \%$ above the $50 \%$ threshold of dependability while the wet season rainfall had a CV of $10.4 \%$ which is very reliable for agriculture. These CVs confirm to the fact that the agricultural sector in the study area has been exposed to variations in rainfall and they have become sensitive as well. The sectors sensitivity to these variations was further investigated through the distribution of questionnaires in the study area. The following aspects on how the variations in rainfall manifest themselves were investigated, namely, the changing trends in rainfall, the onset and terminations of rains, and crop exposure to diseases. Also the degree of crop sensitivity to these variations and diseases was further investigated as well. Figure 5 shows collapsed responses on the direction of changes in rainfall.

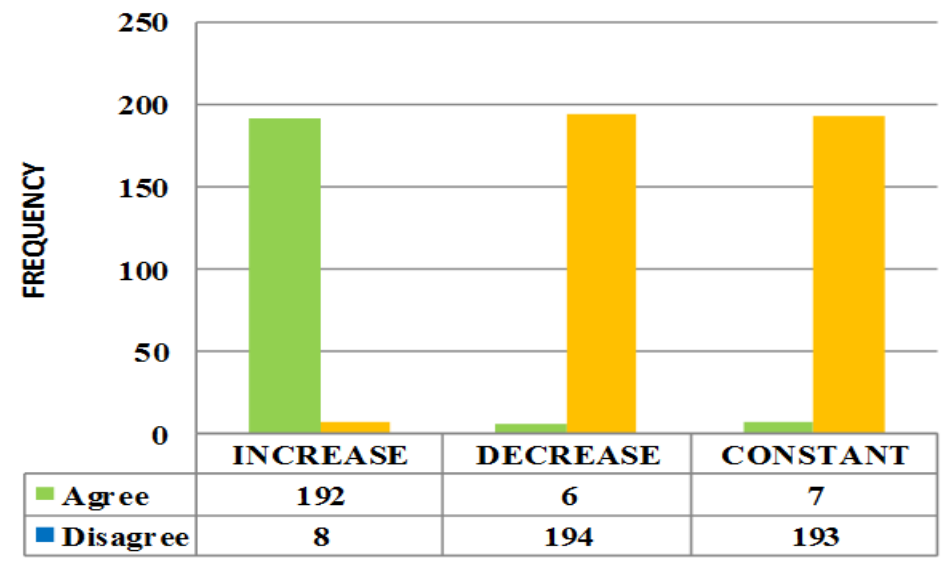

Figure 5. Collapsed responses on the direction of changes in rainfall

Source: Computed from questionnaires.

From the responses on Figure 5, the highest frequency out of the 200 farmers interviewed were of the opinion that rainfall is on the increase in the area. However, wet season rainfall is on an increase but on an annual base rainfall is on a steady decrease. Furthermore, observations have revealed that, rainfall in the last ten years falls intensively for a shorter duration. Also, rainfall periods have been extended in the area. But on a whole, from calculations, it was noticed that rainfall is on a decreasing trend in the study area.

The onset and termination of rains was investigated in order to see how these farmers perceived crop exposure and sensitivity to this situation. Early rains in this context are rains that come earlier than expected between February and early March as has been the case in the last 6years in the area. While delayed rains on the other hand stood for the rains that come by the end of March or in April as was the case for years like 2003, 2004, and 2007, 2008. Figure 6 presents responses on the trends of change in rainfall onset and termination for the study period considered. From the responses, 197 respondents agreed that there has been early start and end of rains while 3 respondents disagreed that there has been late start of rains. One hundred and ninety-seven people disagreed that rainfall has been constant with only seven agreeing that it has been constant. These results again confirmed that truly rainfall over time has not remained the same as perceived by the farmers. 


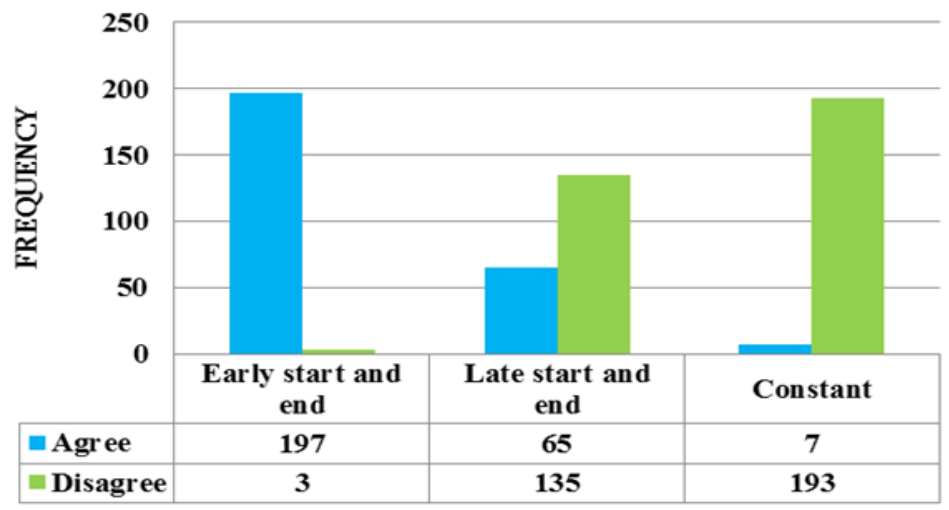

Figure 6. Responses on the trends in the changes in rainfall

Source: Computed from questionnaires.

The percentage distribution of correspondents on the degree of crop species sensitivities to both early and late onset of rains is presented on Tables 3 and 4. Results, from farmer's perception on the degree to which crops are vulnerable as a function of delayed rains revealed that black beans are not affected in the low lands with an acceptance percentage of 70. Furthermore, an analysis on the effects of delay rains in the midlands and highlands revealed that red beans and white beans are only moderately affected in these ecological zones. This implies that the black bean is suitable for the lowlands while the red and white beans are suitable for the midlands and highlands in conditions of delayed rains. This confirms the findings by Romain, (2001) that small seeded bean seeds are suitable in lowland areas that normally experience higher temperatures as opposed to larger seeded bean seeds that will not do well in such conditions like the MEDINO beans in the study area.

From Table 3, three potato species are cultivated in the sub-division, specifically in the midlands and the highland ecological zones. An analysis of farmer's perception showed that the mondial species of potatoes is badly affected in the midlands of Taku, Ntuudip and Shen with a $65 \%$ acceptance rate. Furthermore, $65 \%$ of farmers attested to the fact that spunta is badly affected in the highlands while cipera is less affected in the highlands with a $70 \%$ confirmation. In addition, Cipera by nature of its kind is resistant to blight, which is the highest disease attacking potatoes in this study area. Consequently, the cipera is more suitable in the highlands. This could be explained by the fact that a majority of midland villages are located on the windward side of the ridge where rainfall is higher than the villages of the highlands. Midland villages are, Taku, Ntudip, Nshi-Ntaba just to name a few.

Table 3. Perceptions which Crops are Affected by Delayed Rains in Ndu Sub-Division from 1981 to 2014

\begin{tabular}{|c|c|c|c|c|c|c|c|c|c|}
\hline \multirow[t]{2}{*}{ Crop Type } & \multicolumn{3}{|c|}{ Badly Affected (\%) } & \multicolumn{3}{|c|}{ Moderately Affected (\%) } & \multicolumn{3}{|c|}{ Not Affected at All (\%) } \\
\hline & L1 & L2 & L3 & L1 & L2 & L3 & L1 & $\mathrm{L} 2$ & L3 \\
\hline \multicolumn{10}{|l|}{ BEANS } \\
\hline Red beans & 0 & 0 & 0 & 70 & 47 & 80 & 0 & 3 & 0 \\
\hline White beans & 0 & 0 & 0 & 70 & 46 & 80 & 0 & 4 & 0 \\
\hline Black beans & 0 & 0 & 0 & 0 & 3 & 80 & 70 & 47 & 0 \\
\hline MEDINO & 0 & 0 & 0 & 30 & 3 & 80 & 40 & 47 & 0 \\
\hline \multicolumn{10}{|l|}{ POTATO } \\
\hline Modial species & l & 59 & 0 & l & 22 & 80 & l & 0 & 0 \\
\hline Cipera species & l & 35 & 0 & l & 20 & 10 & I & 25 & 70 \\
\hline Spunta species & l & 30 & 65 & l & 14 & 15 & l & 36 & 0 \\
\hline \multicolumn{10}{|l|}{ MAIZE } \\
\hline White maize & 0 & 0 & 20 & 14 & 14 & 60 & 56 & 36 & 0 \\
\hline Yellow maize & 10 & 20 & 10 & 5 & 13 & 25 & 65 & 37 & 55 \\
\hline
\end{tabular}

Source: Appendix 1. 
Key

L1= Lowland (Lowland micro ecological zone)

L2 $=$ Midlands (Midland micro ecological zones)

L3= Highlands (High land micro ecological zone)

The results on Table 3 showed that averagely, no maize type is badly affected in all three ecological zones with an average response of about 10 to $20 \%$, attesting to this actuality in the three micro ecological zones. Analysis shows that white maize is moderately affected by delayed rains in the midlands and highlands giving a percentage response of 60 to $66 \%$. Yellow maize is less affected in the lower altitude. This had a response percentage of $65 \%$ confirming to the fact that yellow maize is less affected by delayed rains. In effect, in situations of delayed rains, more of red maize should be planted in the three ecological zones.

The results on Table 4 shows that red beans and white beans are badly affected by early rains in the lowlands; $70 \%$ of the lowland population attested to this fact. These bean species are only moderately affected in the midlands and highlands in circumstances of early rains, with a response rate of $80 \%$. Black beans and red beans are not affected in the lowlands by these early rains. This goes to confirm the agronomic studies which proved that small seeded bean species are more resistant to high temperatures than large seeded beans. The lowland altitude areas of the Mbaw plains, Ntaye, Luh, and Ntamru experience higher temperatures than those of the higher altitudes. This spatiality can be explained by the effect of continentality, coupled with the increasing trend in global temperatures.

All maize species are only moderately affected with early onset of rains. But in situations where the rain goes away for a long time, it becomes disastrous for the maize plants. This is because water requirements for maize are high. Seventy percent of the respondents in the three micro ecological zones admitted that the yellow and white maize types are moderately affected by early rains. But the yellow maize type is most affected in the highland ecological zone with a $70 \%$ confirmation of this in the highlands.

Table 4. Perceptions Which Crops Are Affected by Early Onset of Rains in Ndu Sub-Division from 1981 To 2014

\begin{tabular}{|c|c|c|c|c|c|c|c|c|c|}
\hline \multirow[t]{2}{*}{ Crop type } & \multicolumn{3}{|c|}{ Badly affected (\%) } & \multicolumn{3}{|c|}{ Moderately affected (\%) } & \multicolumn{3}{|c|}{ Not affected at all (\%) } \\
\hline & L1 & $\mathrm{L} 2$ & L3 & L1 & L2 & L3 & L1 & L2 & L3 \\
\hline \multicolumn{10}{|l|}{ BEANS } \\
\hline Red beans & 70 & 50 & 0 & 0 & 0 & 8 & 0 & 0 & 72 \\
\hline White beans & 70 & 0 & 0 & 0 & 50 & 80 & 0 & 0 & 0 \\
\hline Black beans & 0 & 0 & 80 & 0 & 50 & 0 & 70 & 0 & 0 \\
\hline Medino & 70 & 0 & 0 & 0 & 50 & 80 & 0 & 0 & 0 \\
\hline \multicolumn{10}{|l|}{ POTATO } \\
\hline Modial species & l & 35 & 5 & l & 44 & 75 & l & 0 & 0 \\
\hline Cipera species & I & 40 & 0 & / & 14 & 7 & l & 25 & 73 \\
\hline Spunta species & l & 0 & 0 & l & 38 & 80 & l & 40 & 0 \\
\hline \multicolumn{10}{|l|}{ MAIZE } \\
\hline White maize & 8 & 44 & 76 & 49 & 6 & 4 & 13 & 0 & 0 \\
\hline Yellow maize & 0 & 0 & 0 & 18 & 14 & 80 & 52 & 30 & 0 \\
\hline
\end{tabular}

Source: Field work, 2015.

Key

L1 = Lowland (Lowland micro ecological zone)

L2 $=$ Midlands (Midland micro ecological zones)

L3 = Highlands (High land micro ecological zone) 


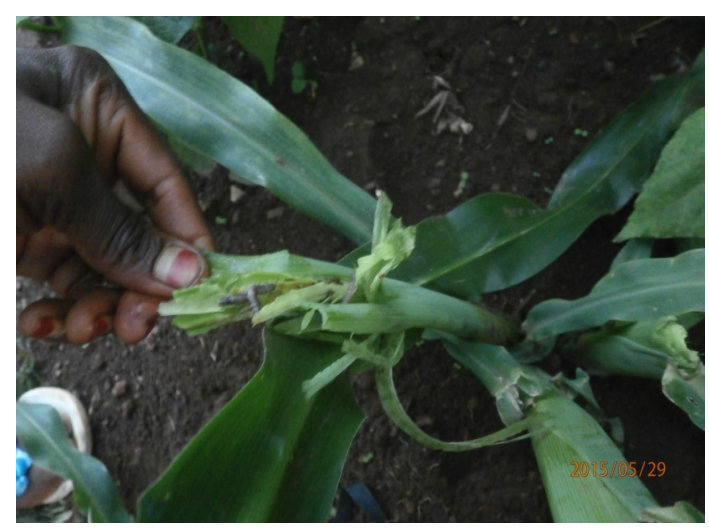

Figure 7. Stem borers in the midrib of a maize plant in Kakar Ndu Sub-Division Source: Field Work (2015).

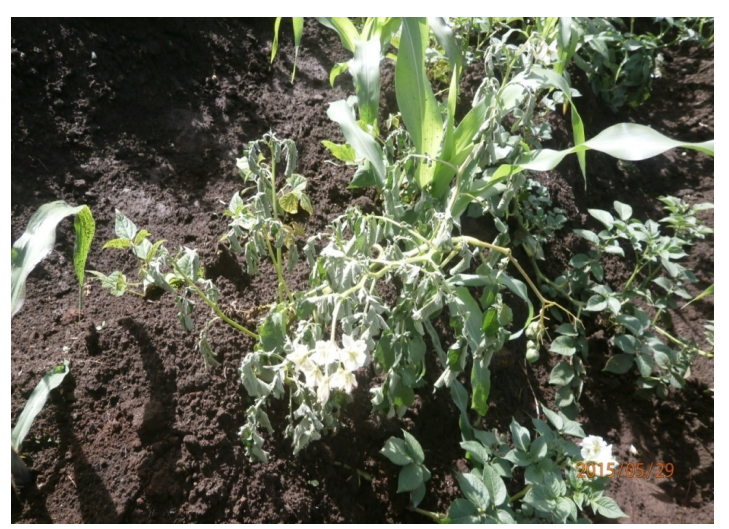

Figure 8: Spunta Potatoe plant affected by bacteria wilt in Mbiyeh (notice the weathered nature of the leaves) Source: Field work (2015).

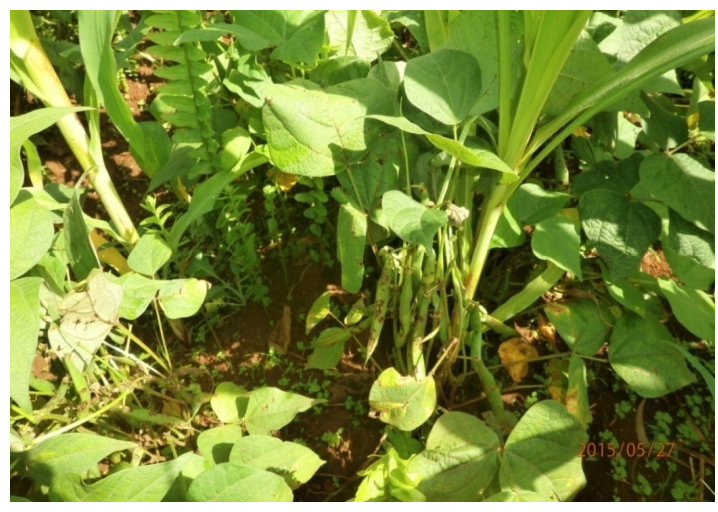

Figure 9. Angular Leave spot disease attack on bean plants, Taku village in Ndu Source: Field work (2015). 


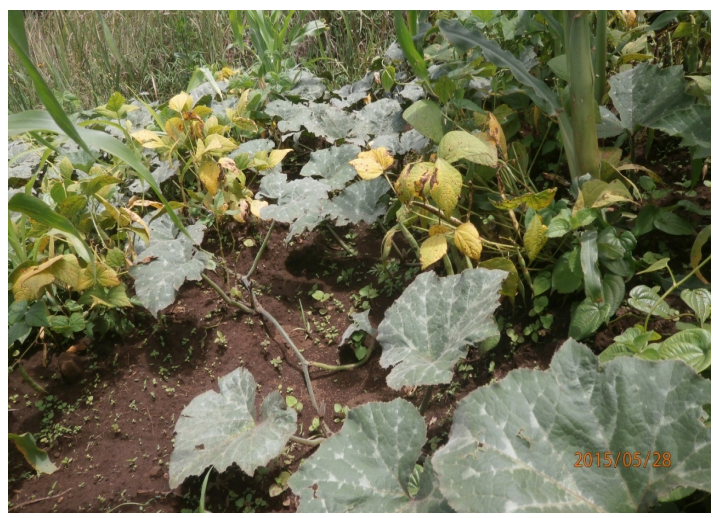

Figure 10. Bean plants affected by fusarium root rot in Njimkang village, Ndu

Source: Field work (2015).

Field observations showed that the food crop sector has been exposed to more pest and disease attack in the last ten years as shown in Figure 7, 8, 9 and 10. Some of the diseases observed were not originally identified at the level of the Sub-Divisional Delegation of Agriculture, for example, the angular leave spot disease and fusarium root rot disease affecting beans. This was the most significant bean disease in the field in 2015 during the first cycle cropping that affected the bean plants. An early attack of beans by fusarium prevents the bean plants from producing bean seeds. This has a severe effect on beans production as testified by farmers in the field.

\section{Spatial Presentation of Diseases in the Three Ecological Zones}

Results from respondent's perceptions on the spatial distribution of pest and diseases attacking crops are presented in Tables 5, 6, and 7. The results proved that maize streak virus in the three ecological zones are prevalent more in the lowlands and attacks more of the yellow maize species. Out of the 80 cultivators interviewed in the lowland with regards to maize streak virus, $62 \%$ of the 80 cultivators admitted that there is a significant attack on the yellow maize species and $38 \%$ rather pointed the attack to the white species of maize. This shows that this disease is a threat to maize cultivation in the lowlands. An average of about $45 \%$ of the 160 maize cultivators interviewed in the midlands and highlands agreed that the disease is common to the midlands and highlands but not as significant as it is the case with the lowland areas of Mbaw and Ntaba.

Ninety people were interviewed in the Highland Zone. Seventy-five percent of the 90 people interviewed were of the opinion that the stem borers are a threat to maize in this ecological zone and the attack seem to be more significantly noticed with the white maize probably because the white maize is more vulnerable to attack in this zone. Out of the 80 farmers in the midlands, $50 \%$ admitted that this disease attacks their maize plants both the yellow and the white types. The disease attacks more of the white maize species in the lowlands. On a whole, this disease is common and severe to all the ecological zones. The spatial distribution of the blast fungus attack on the maize plant in all the three ecological zones revealed that blast attacks yellow maize significantly in all the three ecological zones, with the highlands recording the highest attack, with a percentage of $67 \%$. The high humidity of this zone favours the spread of the disease. White maize is less vulnerable to blast attack in all ecological zones.

Responses as to the intensity of weevil attack on maize showed that this insect is common to all the ecological zones with white maize being the most vulnerable to attack in the midlands and highlands giving a response rate of $75 \%$. Therefore, white maize attack by the insect in the midlands and highlands is more common while the lowlands attack on yellow maize is high coupled with the increasing trend noticed in temperatures which provides favourable conditions for the breeding of these insects. Late blight is a common disease that attacks beans in the three ecological zones. Analysis from the responses showed that the white bean species is less vulnerable in the lowlands. The midlands and highlands register the highest attack for late blight for white beans. This could be explained by the fact that most midland and highland villages are located on the side of the ridge that receives much rain. So this initiates conditions for attack by blight. The black bean species is less vulnerable in the lowlands because small seeded bean species are more resistant to high temperatures than the larger seeded bean types.

Aphid attack is a common disease that attack bean plants in the field. The statistics revealed that the disease is 
not confined to a particular ecological zone or bean type. All bean types are liable to attack. Black beans and the white beans registered the list attack in the lowlands. Aphids attack white beans more significantly in the midlands and highlands. This can be accounted for by the moderate temperatures of this area that favour their proliferation. Black and the red beans types are significantly attacked by aphids in the midlands and highlands. This is the case of 2015 where each farm did not register less than 100bean stems attacked by this disease beside others (Field work, 2015).

Potatoes is a midland and highland crop because of its high sensitivity to the increased temperatures that are associated with lowland areas. There is a spatial distribution of late blight attack on all three potato species in the study area. The least percentage for blight attack was registered for spunta in the midlands with a response rate of $21 \%$ confirming to the attack. $40 \%$ was registered in the highlands. $43 \%$ of the respondents in the midlands confirm the attack of cipera in this zone and only $20 \%$ were of the opinion that blight significantly attack cipera in the highlands. Blight attack is fairly distributed on the mondial species in both ecological zones. However, cipera is more resistant to blight attack in the highlands than the midlands while spunta is less vulnerable to blight attack in the midlands. Bacterial wilt has become very common to all potato species but with variations in the intensity of attack. An analysis of data from the questionnaires revealed that spunta is more susceptible to attack by the bacterial wilt while cipera and mondial are fairly attacked by this disease.

\section{Establishing Relationship Using Infereitial Tools}

This section shows the relationship between rainfall variability and food crop exposure and sensitivity. From Table 8, rainfall shows a P-value of 0.1959 which implies that rainfall, statistically accounts for $19.59 \%$ variation in maize production for the period under consideration. Therefore, a weak relationship exists between maize productions and rainfall. The remaining $80.41 \%$ of the variations in maize production could be accounted for by other factors, namely, farm inputs, soil structure and quality as well as the seed varieties cultivated.

Table 5. Percentage of responses from farmers at different altitudes on the degree of pests and diseases attack on Maize

\begin{tabular}{llllllll}
\hline $\begin{array}{c}\text { Crop } \\
\text { type }\end{array}$ & \multicolumn{1}{c}{ Disease name } & \multicolumn{2}{c}{ Lowland } & \multicolumn{2}{c}{ Midland } & Highland \\
& & $\begin{array}{l}\text { White } \\
\text { Maize } \\
(\%)\end{array}$ & $\begin{array}{l}\text { Yellow maize } \\
(\%)\end{array}$ & $\begin{array}{l}\text { White maize } \\
(\%)\end{array}$ & $\begin{array}{l}\text { Yellow maize } \\
(\%)\end{array}$ & $\begin{array}{l}\text { White maize } \\
(\%)\end{array}$ & $\begin{array}{l}\text { Yellow maize } \\
(\%)\end{array}$ \\
\hline \multirow{2}{*}{ Maize } & $\begin{array}{l}\text { Maize streak } \\
\text { virus }\end{array}$ & 38 & 62 & 53 & 47 & 60 & 40 \\
& $\begin{array}{l}\text { Maize stem } \\
\text { borers }\end{array}$ & 56 & 44 & 50 & 50 & 75 & 25 \\
& $\begin{array}{l}\text { Blast fungus } \\
\text { Weevil attack }\end{array}$ & 38 & 62 & 40 & 60 & 33 & 67 \\
\end{tabular}

Table 6. Percentage of responses from farmers at different altitudes on the degree of pests and diseases attack on Beans

\begin{tabular}{|c|c|c|c|c|c|c|c|c|c|c|c|c|c|}
\hline \multirow[t]{2}{*}{ Crop type } & \multirow[t]{2}{*}{ Disease name } & \multicolumn{4}{|c|}{ Lowland (\%) } & \multicolumn{4}{|c|}{ Midland (\%) } & \multicolumn{4}{|c|}{ Highland (\%) } \\
\hline & & Red & White & Black & Medino & Red & White & Black & Medino & Red & White & Black & Medino \\
\hline \multirow[t]{2}{*}{ Beans } & Late blight & 31 & 19 & 25 & 25 & 29 & 29 & 28 & 14 & 22 & 33 & 28 & 17 \\
\hline & Aphids & 25 & 20 & 10 & 25 & 42.5 & 30 & 48 & 35.5 & 20 & 30 & 25 & 15 \\
\hline
\end{tabular}

Table 7. Percentage of responses from farmers at different altitudes on the degree of pests and diseases attack on Irish Potatoes

\begin{tabular}{clllllll}
\hline Crop Type & Disease Name & \multicolumn{3}{c}{ Midland } & Highland \\
\hline & & Mondial (\%) & Cipira (\%) & Spunta (\%) & Mondial (\%) & Cipira (\%) & Spunta (\%) \\
& Late blight & 36 & 43 & 21 & 25 & 25 & 40 \\
Irish potatoes & Bacterial wilt & 21 & 36 & 43 & 30 & 29 & 41 \\
& & &
\end{tabular}

Source: Field Work, (2015). 
Table 8. Results for Maize Production in Ndu Sub-Division

\begin{tabular}{|c|c|c|c|c|}
\hline \multicolumn{5}{|c|}{ Dependent Variable: MAIZE } \\
\hline \multicolumn{5}{|c|}{ Method: Least Squares } \\
\hline \multicolumn{5}{|c|}{ Date: 09/17/15; Time: 13:46 } \\
\hline \multicolumn{5}{|l|}{ Sample: 20002014} \\
\hline \multicolumn{5}{|c|}{ Included observations: 15} \\
\hline Variable & Coefficient & Std. Error & t-Statistic & Prob. \\
\hline Rainfall & 19.51966 & 14.17721 & 1.376834 & 0.1959 \\
\hline $\mathrm{C}$ & -172583.8 & 76363.27 & -2.260036 & 0.0451 \\
\hline R-squared & 0.593187 & \multicolumn{2}{|c|}{ Mean dependent var } & 38583.27 \\
\hline Adjusted R-squared & 0.482238 & \multicolumn{2}{|c|}{ S.D. dependent var } & 16304.81 \\
\hline S.E. of regression & 11732.23 & \multicolumn{2}{|c|}{ Akaike info criterion } & 21.80125 \\
\hline Sum squared resid & $1.51 \mathrm{E}+09$ & \multicolumn{2}{|c|}{ Schwarz criterion } & 21.99006 \\
\hline Log likelihood & -159.5093 & \multicolumn{2}{|l|}{ F-statistic } & 5.346486 \\
\hline Durbin-Watson stat & 2.910389 & \multicolumn{2}{|c|}{ Prob(F-statistic) } & 0.016228 \\
\hline
\end{tabular}

Source: Questionnaire and Rainfall data (2015).

Table 9 presents a P-value of 0.5087 for rainfall. This means that rainfall accounts for $50.87 \%$ of variations in beans production. The P-value shows that there is no significant relationship between rainfall and beans production because the P-value is $>0.05$ threshold for a significant relationship to exist. Furthermore, the statistics in Table 9 shows that a $1 \mathrm{~mm}$ increase in rainfall will account for 2.493478 tons variation in annual bean production. The climatic requirements of the bean plants are usually very sensitive. Bean requires rainfall that alternate with sunshine to enable the vegetative growth of the plant to be successful with good yields.

Table 9. Results for Beans production in Ndu Sub-Division

\begin{tabular}{|c|c|c|c|c|}
\hline \multicolumn{5}{|c|}{ Dependent Variable: BEANS } \\
\hline \multicolumn{5}{|c|}{ Method: Least Squares } \\
\hline \multicolumn{5}{|c|}{ Date: 09/17/15; Time: 13:47 } \\
\hline \multicolumn{5}{|c|}{ Sample: 20002014} \\
\hline \multicolumn{5}{|c|}{ Included observations: 15} \\
\hline Variable & Coefficient & Std. Error & t-Statistic & Prob. \\
\hline Rainfall & 2.493478 & 3.650065 & 0.683133 & 0.5087 \\
\hline Temperature & 1727.209 & 794.6902 & 2.173437 & 0.0525 \\
\hline Humidity & -48.92349 & 243.8690 & -0.200614 & 0.8447 \\
\hline $\mathrm{C}$ & -24692.03 & 19660.49 & -1.255922 & 0.2352 \\
\hline R-squared & 0.363975 & \multicolumn{2}{|c|}{ Mean dependent var } & 9078.893 \\
\hline Adjusted R-squared & 0.190513 & \multicolumn{2}{|c|}{ S.D. dependent var } & 3357.265 \\
\hline S.E. of regression & 3020.581 & \multicolumn{2}{|c|}{ Akaike info criterion } & 19.08746 \\
\hline Sum squared resid & $1.00 \mathrm{E}+08$ & \multicolumn{2}{|c|}{ Schwarz criterion } & 19.27628 \\
\hline Log likelihood & -139.1560 & \multicolumn{2}{|c|}{ F-statistic } & 2.098304 \\
\hline Durbin-Watson stat & 2.843539 & \multicolumn{2}{|c|}{ Prob(F-statistic) } & 0.158586 \\
\hline
\end{tabular}

Source: Questionnaire and Rainfall data (2015). 
Table 10. Results for potatoes production in Ndu Sub-Division

\begin{tabular}{|c|c|c|c|c|}
\hline Dependent Variable: & & & & \\
\hline Method: Least Squar & & & & \\
\hline Date: $09 / 17 / 15$; Tim & & & & \\
\hline Sample: 20002014 & & & & \\
\hline Included observation & & & & \\
\hline Variable & Coefficient & Std. Error & $\mathrm{t}$-Statistic & Prob. \\
\hline Rainfall & 16.11786 & 14.85318 & 1.085146 & 0.3011 \\
\hline Temperature & 7652.284 & 3233.826 & 2.366325 & 0.0374 \\
\hline Humidity & -312.4157 & 992.3741 & -0.314816 & 0.7588 \\
\hline $\mathrm{C}$ & -139472.4 & 80004.25 & -1.743312 & 0.1091 \\
\hline R-squared & 0.432972 & Mean depe & & 13371.73 \\
\hline Adjusted R-squared & 0.278328 & S.D. depen & & 14469.03 \\
\hline S.E. of regression & 12291.62 & Akaike inf & & 21.89440 \\
\hline Sum squared resid & $1.66 \mathrm{E}+09$ & Schwarz c & & 22.08322 \\
\hline Log likelihood & -160.2080 & F-statistic & & 2.799799 \\
\hline Durbin-Watson stat & 2.123062 & Prob(F-sta & & 0.089626 \\
\hline
\end{tabular}

Source: Questionnaire and Rainfall data (2015).

From Table 10, a P-value for rainfall was recorded as 0.3011 meaning that there is no significant relationship between rainfall and potatoes production according to the statistical role. This value also means that $30.11 \%$ of the variation in potatoes production is accounted for by rainfall and a $1 \mathrm{~mm}$ increase in rainfall will reduce potatoes production by 16.117 tons annually. The potatoes plant is very sensitive to heavy rainfall. This can partly be accounted for by the weak relationship that exists between rainfall and potatoes production. The late blight and early blight disease that is common in the study area have registered their highest vulnerabilities with years of increased rainfall, namely, 1999, 2004, and 2009. The blight causing bacterium proliferates in high humidity and rainfall conditions.

The study found out that though favourable rainfall is a necessary condition for the growth of food crops, the data sourced and analysed revealed that there is a variation in the relationships that exists between food crop production and the climatic parameter of rainfall in the study area. The regression analysis revealed that there is no significant relationship between maize, beans, potatoes and rainfall variability in the study area for the time period under consideration. The regression results were further corroborated with the correlation technique which further revealed a weak correlation between maize, beans, potatoes and rainfall variations in Ndu from 1981 to 2014.

\section{Conclusion}

From the foregone account, the importance of subsistence agriculture in Ndu cannot be underestimated because it plays an important role in the livelihood of the population. Large populations in the rural areas depend solely on rain-fed agriculture for their subsistence with poverty levels stagnating and societal flexibility to climatic variations not improving. Observed climatic trends have been changing with their very unambiguous variations as rainfall shows a significant negative trend. These have all been indicated by the increase exposure of the food crop sector to frequent extended dry periods as well as torrential downpours over the years from 1981 to 2014. However, subsistence farmers have already adopted some coping strategies for the recurrent variable climatic conditions that have prevailed over the past years. These indigenous adaptations range from changing planting dates and crop varieties, farmland extensification, irrigation and soil conservation practices, the use of local indicators and switching to second cycle cropping. But, adaptation by subsistent farmers should go beyond the above mentioned practices or else climatic variation and change will continue to have increasingly devastating impacts on subsistent farmers in Ndu Sub-Division. Policy makers should pay particular attention on the role of local and indigenous knowledge when adaptation is concerned. These are some of the type of experiences passed down from generation to generation and offer very invaluable information regarding coping options that would not be acquired through other channels. More importantly, special considerations should also be given in tackling the highlighted constraints perceived by subsistence farmers towards adaptation. Agricultural vulnerability showed a variation in its degree with different species at different altitudes. It is for this reason that farmers are advised to plant those crops that have proved to be resistant at certain altitudes like black and red beans in the lowlands and cipera in the midlands and highlands. 
Climate variability and change have minimally accounted for agricultural vulnerability in Ndu Sub-Division.

\section{Recommendations}

The process of adaptation is not new; the idea of incorporating current climatic situations into policy making is what seems to be new. Policy intervention is required. However, to ensure that farmers can respond when they need to and the availability of support as they consider their options, the policy options should be an extension of development designed to eradicate the structural causes of poverty and food insecurity. For the adaptive capacity of the agricultural sector to be increased in Cameroon and Ndu in particular, policy makers should ensure an engagement of some core ministries in the Republic of Cameroon, namely, the Ministry of Economy and Finance, Ministry of Women Empowerment and the Family, the Ministry of Scientific Research \& Innovation alongside the Ministry of Communication, in order to ensure strong government support on agricultural production through their different activities. Furthermore, the bottom-top approach should be encouraged in the adaptation and mitigation process. This will go a long way to integrate both indigenous and modern methods of adaptation to reduce agricultural vulnerability in the sub-division. Also, with this method, the indigenous farmers feel important and recognized and will cooperate fully with the government as opposed to when every instructions are given to them from the top whereas they are only to implement and not contribute their own ideas.

Through this delegation, farmers should be sensitized to turn to more sustainable agricultural practices such as the no till agriculture, crop rotation, the use of organic manures or biochare which are good carbon sequesters while avoiding soil burning, bush clearance using fire and the practice of sustainable deforestation by reforesting with environmentally friendly tree species. This will significantly minimize food crop vulnerability to climate variability and change. In addition, the field extension workers should sensitize the farmers in the hinterlands rather than concentrating their sensitizations around Ndu town only, as was discovered during field work that the level of awareness decreases as you move away from Ndu town to the hinterlands. Again, the Sub-Divisional Delegation should influence the government to subsidize farm inputs for farmers which will go a long way to increase their adaptive capacities to climate variability. Better still, incentives should be given to farmers to improve production and increase their adaptive capacities. From findings, crop cultivators are encouraged to engage more in second cycle of cropping since the crops are least affected by diseases as opposed to first cycle cropping. Furthermore, lowland crop cultivators should plant more of small seeded bean seeds because findings showed that they are moderately affected by the vagaries of climate variability in this zone. Midland and highland zones are recommended to plant more of the large seeded bean seeds because of their suitability and resistant to disease in these zones.

\section{Conflict of interests}

The authors declare that there is no conflict of interests regarding the publication of this paper.

\section{Reference}

Adger, W. N. (1999). Social Vulnerability to Climate Change and Extremes in Coastal Vietnam. World Development, 2, 249-269.

Adger, W. N. (2006). Vulnerability. Global Environmental Change, 16(3), 268-281.

Amawa, S. G. (1999). Land Degradation on the Mbum Plateau (North West Province of Cameroon). Unpublished MSc Thesis.

Amawa, S. G. (2001). Variation in Spring Discharge on the Mbum Plateau, (Nest West Region of Cameroon). In Lambi (ED) Readings in Geography, Unique Printers Bamenda

Atkins, J., Mazzi, S., \& Ramlogan, C. (1998). A Study on the Vulnerability of Developing and Island States: A Composite Index. Commonwealth Secretariat, UK. Australia: Queensland Department of Primary Industries.

Ayoade, J.O. (1992). Introduction to Climatology for the Tropics (3rd ed.). Spectrum books Ltd Ibadan.

Cothren, J. T., Matocha, J. E., \& Clark, L. E. (2000). Integrated crop systems. J. Prod. Agric., 9, 180-186.

Critchley, W., \& Siegert, K. (1991). Water Harvesting: A Manual for the Design and Construction of Water Harvesting Schemes for Plant Production. FAO, AGL/MISC/17/91.

Divisional Delegation for Agriculture and Rural development; Nkambe. (2015).

Handmer, J. W., Dovers, S., \& Downing, T. E. (1999). Societal Vulnerability to Climate Change and Variability. Mitigation and Adaptation Strategies for Global Change, 4, 267-281. 
IPCC. (2007). Climate Change 2007: Impacts, Adaptation and Vulnerability. In M. L. Parry, O. F. Canziani, J. P. Palutikof, P. J. Van der, \& C. E. Hanson (Eds.), Contribution of Working Group II to the Fourth Assessment Report of the Intergovernmental Panel on Climate Change. Cambridge University Press, Cambridge, United Kingdom and New York, NY, USA.

Mendelsohn, R. (2009). Climate Change Impacts on Agriculture. In R. Evenson, P. Pingali, \& P. Schultz (Eds.), Handbook of Agricultural Economics: Agricultural Development (Vol.III, Chapter 19).

Rosenzweig, C., \& Hillel, D. (1995). Potential Impacts of Climate Change on Agriculture and Food Supply. Consequences of Climate Change on Agriculture and Food Supply. Consequences, 1(2). Retrieved from http:/www.gcrio.org/CONSEQUENCES/summer95/agriculture/html

Storch, H. V., \& Zweir, F. W. (1999). Statistical Analysis in Climate Research. Cambridge University Press Sub Divisional Delegation for Agriculture and Rural Development; Ndu 2014.

\section{Copyrights}

Copyright for this article is retained by the author(s), with first publication rights granted to the journal.

This is an open-access article distributed under the terms and conditions of the Creative Commons Attribution license (http://creativecommons.org/licenses/by/4.0/). 